\title{
Comparison of virulence of hybridized entomopathogenic nematode Heterorhabditis bacteriophora (Rhabditida: Heterorhabditidae) strains and their parents ${ }^{1}$
}

\author{
Hibrit entomopatojen nematod Heterorhabditis bacteriophora ırklarının ebeveynlerine \\ göre etkinliklerinin karşılaştırılması
}

Yasemin KONGU ${ }^{2}$

I. Alper SUSURLUK ${ }^{3 *}$

\section{Summary}

Efficacy of Heterorhabditis bacteriophora Poinar, 1976 (Rhabditida: Heterorhabditidae) species can be changed on targeted insect pests in different climatic zone. In this study, six different $H$. bacteriophora strains, which isolated in different cities [Antalya (H.b. 6), Çanakkale (H.b. 876), Kırklareli (H.b. 17), İzmir (H.b. HIZ) and Adana (H.b.10)] from Turkey, were hybridized and their virulence were determined on the last instar of Galleria mellonella (Lepidoptera: Pyralidae) at six different dosages. Male and female individuals of having lowest virulence were crossbred with other strain females and males in vitro conditions. Ten different strains were obtained by hybridization and their virulence was compared with their parent and each other on the last instar larvae of G. melonella. The results showed that $70 \%$ of hybridized strains were more effective than their parents. The results indicated that male and female individuals have different effect on the virulence of the hybridized strains. The hybridized strains, which were more effective than their parents, were influenced from female with $42.9 \%$ and from male with $57.1 \%$.

Key words: Heterorhabditis bacteriophora, entomopathogenic nematodes, virulence, hybridization, in vitro

\section{Özet}

Yüksek biyolojik mücadele potansiyeline sahip olan Heterorhabditis bacteriophora Poinar, 1976 (Rhabditida: Heterorhabditidae) türünün hedef alınan zararlı böcek üzerindeki etkinliği farklı iklim özelliklerine sahip olan bölgelerde değişiklik göstermektedir. Bu çalışmada; Antalya (H.b. 6), Çanakkale (H.b. 876), Kırklareli (H.b. 17), İzmir (H.b. HIZ), Şanlıurfa (H.b. HSU) ve Adana (H.b. 10) illerinden izole edilmiş olan 6 farklı H. bacteriophora izolatı kullanılmıştır. Bu izolatların etkinlikleri Galleria mellonella (Lepidoptera: Pyralidae)' nın son dönem larvaları üzerinde 6 farklı uygulama dozunda belirlenmiştir. En düşük etkinlik değerine sahip olan izolatın erkek ve dişi bireyleri ile denemelerde kullanılan diğer tüm ırkların erkek ve dişi bireyleri in vitro ortam koşullarında hibritlenerek 10 farklı ırk elde edilmiştir. Hibridizasyon sonucunda elde edilen ırkların G. mellonella larvaları üzerindeki etkinlikleri ebeveyn ırklar ile aynı şekilde belirlenmiştir. Çalışma sonunda ebeveyn ve hibrit ırklara ait olan etkinlik verileri karşılaştııımış ve elde edilen 10 yeni hibrit ırkın \%70' inin ebeveynlerine göre yüksek, \%30' unun ise ebeveynlerine göre daha düşük değerde etkinlik gösterdiği tespit edilmiştir. Ayrıca hibrit ırkların böcek üzerindeki etkinlik değeri üzerine erkek ve dişi bireylerin farklı etkiler gösterdiği de tespit edilmiştir. Ebeveynlerine göre yüksek etkinlik değerine sahip olan hibrit ırkların etkinlik değerlerinin \%57.1' inin erkek, \%42.9'unun ise dişi bireylerin etkisi altında kaldığı bulunmuştur.

Anahtar sözcükler: Heterorhabditis bacteriophora, entomopatojen nematod, etkinlik, hibridizasyon, in vitro

\footnotetext{
${ }^{1}$ This study is a part of the project supported by TUBITAK-TOVAG 1100161 and also is a part of MSc thesis of the first author accepted on 07.06 .2012 by the Graduate School of Natural and Applied Sciences of Uludag University in Bursa, Turkey

2 Izmir Agricultural Quarantine Directorate, 35230 Alsancak, Izmir, Turkey

${ }^{3}$ Uludağ University, Agriculture Faculty, Plant Protection Department, 16059 Nilüfer, Bursa, Turkey

* Sorumlu yazar (Corresponding author) e-mail: susurluk@uludag.edu.tr

Alınış (Received): 05.12.2013 Kabul ediliş (Accepted): 29.04.2014
} 


\section{Introduction}

Heterorhabditis bacteriophora (Rhabditida: Heterorhabditidae) Poinar 1976, is an entomopathogenic nematode (EPNs) species used successfully in biological control against insect pests (Ehlers, 1996). This species is well known all over the world and were isolated from Turkey as well (Özer et. al., 1995; Susurluk et. al., 2003; Kepenekçi, 2002; Hazır et. al., 2003; Kepenekçi \& Susurluk, 2003; Susurluk, 2006; Susurluk et. al., 2009, 2011). The $3^{\text {rd }}$ juvenile stage of this nematode, which is named infective juvenile (IJ) also, is nonfeeding and free living in soil. Furthermore it is symbiotically associated with bacterium, Photorhabdus luminescens, which is carried in the intestine of IJs at varying number ranging 200 from 2000 (Bird \& Akhurst, 1983). IJs can survive until finding new hosts up to 8 months in soil (Ehlers, 1996). When they find a suitable host, they enter their hosts via natural opening such as mouth, anus, spiracles, or directly the cuticle (Bedding \& Molyneux, 1982; Poinar, 1990; Wang \& Gaugler, 1998). Then, IJs release their symbiotic bacterium cells into the haemocoel (Poinar et. al., 1977). IJs feed on bacterium cells and host tissue while the bacterium cells grow in the host. After penetration the host is killed by means of septicemia within 24-48 h (Akhurst, 1983; Forst \& Nealson, 1996). Developing IJs of $H$. bacteriophora reach self-fertile hermaphrodites that are female phenotype in first generation. Then, they generate amphimictic males and females and IJs in second generation (Poinar, 1975; Strauch et. al., 1994). New adult generations develop if enough nutrients exist in haemocoel of insects. Otherwise they create IJs, which emerge into the soil where they seek out a new host (Kaya \& Gaugler, 1993; Grewal et. al., 1994; Ehlers, 1996).

EPNs can be produced in vivo and in vitro (Friedman, 1990; Lunau et. al., 1993). White Trap method is a basic method for in vivo production (White, 1927; Flanders et. al., 1996; Kaya \& Stock, 1997). Generally, greater wax moth, Galleria mellonella (Lepidoptera: Pyralidae) last instars larvae, which has high susceptibility to EPNs, are used in this method (Shapiro-llan \& Gaugler, 2002). Another technique for production of EPNs is in vitro on solid or liquid cultures (Fridman et. al., 1990; Lunau et. al., 1993; Ehlers, 1996, 2001; Gaugler \& Han, 2002). Isolations of symbiotic bacteria and nematode eggs are the most important points at EPN production for both the solid culture and liquid culture techniques.

Previous study showed that there were individuals, having different reactions in the population of the same EPN species (Gaugler et. al., 1989; Glazer et. al., 1991). H. bacteriophora is hermaphrodite in the first generation, which enables to save any character of $H$. bacteriophora structure. Female and male individuals, which are seen in the second generation, are fertile and their characters are pass down other generations. Thus, a feature can be transferred to $\mathrm{H}$. bacteriophora structure by hybridization of females and males (Zioni et. al., 1992; Johnigk \& Ehlers, 1999 a,b). Moreover, the feature can be protected through hermaphrodites. As a result, tolerance of $H$. bacteriophora is improved against extreme environmental conditions via a selective breeding, which helps obtaining the resistant strains (Strauch et. al. 2004; Ehlers et. al., 2005; Mukuka et. al., 2010 a,b,c,dMukuka et. al., (2010 a, b) had some findings about hybrid vigor. Hybrid vigor and breakdown are usually ascribed to the average fitness of the hybrid offspring, although there will be individual genotypes within the recombinant hybrid offspring that do better or worse than the average (Edmands 1999).

The aim of this study was to compare the virulence of ten different $H$. bacteriophora strains obtained by hybridization with their parent and each other on the last instar larvae of G. mellonella.

\section{Material and Methods}

\section{Isolations of Heterorhabditis bacteriophora and rearing of Galleria mellonella larvae}

Six different $H$. bacteriophora strains, which were isolated from different cities of Turkey, were used in the experiments. H.bacteriophora H.b. 6, H.b. 17, H.b. 10, H.b. HIZ, H.b. HSU and H.b. 876 strains were isolated from Antalya, Kırklareli, Adana, İmir, Şanlıurfa and Çanakkale, respectively. All of them were identified by molecular techniques (PCR-RFLP) (unpublished data). 
The last instar larvae of greater wax moth, G. mellonella, were used in the all experiments because of being sensitive to EPNs. The larvae of the insect were reared in $1000 \mathrm{ml}$ glass jars at $30 \pm 2^{\circ} \mathrm{C}$ on an artificial media according to Wiesner (1993).

\section{Virulence tests of parent strains}

G. mellonella last instars larvae were used in the laboratory tests to determine the virulence of nematode strains,. Virulence of all strains were tested on the last instars larvae at the six different dosages 5, 10, 20, 50, 75 and $100 \mathrm{IJs} / \mathrm{Larva}$. The IJs were 2-week-old. The experiments were carried out in the 24 well plates (each well $1.6 \mathrm{~cm}$ diameter, $1.8 \mathrm{~cm}$ high). Each larva was placed at the bottom of each well and covered with $3 \mathrm{~cm}^{3}$ of sterile sand (particle size: $300-400 \mu \mathrm{m}$ ), which had a water content of $3 \%$. Each larvae was inoculated with different dose, which was applied in $300 \mu$ l of Ringer's solution (Susurluk et. al., 2001). The well plates were closed with parafilm and incubated at $25 \pm 1.5{ }^{\circ} \mathrm{C}$ for 4 days. twenty larvae were used in an experiment to assess the virulence of a strain,.. After incubation, the larvae were removed from the sand and the larvae killed by IJs, were counted to evaluate of efficacy. The results were recorded as Lethal Dose $\left[L D_{50}, L D_{90}\right.$ and $\left.\left.L D_{\text {mean }}\left(L D_{50}+L D_{90}\right) / 2\right)\right]$ at the end of experiments. The experiment was repeated three times for each dose

\section{Hybridization of $\boldsymbol{H}$. bacteriophora strains on in vitro conditions}

Hybridization processes contained the following steps:

\section{Bacteria isolation}

Five G. mellonella last instars larvae were infected with $H$. bacteriophora at the range of 100 IJs per larva as mentioned above (Susurluk et al., 2001, 2003). After infection, larvae were incubated $25 \pm 1.5$ ${ }^{\circ} \mathrm{C}$ for $24 \mathrm{~h}$. At the end of the time, treated larvae were washed with Ringer's solutions and then sterilized with $70 \%$ ethanol for 5 minutes. Each sterilized larva was drilled with a sterile pin for the purpose of obtaining haemolymph where grow bacteria. A drop of haemolymph was taken using a loop and transferred on NBTA agar. Inoculated NBTA agar with bacteria was incubated at $25 \pm 1.5^{\circ} \mathrm{C}$ for 3 days. Then, a colony was taken by loop from colonized bacteria and transferred in the YS liquid medium. The YS medium was incubated at $25 \pm 1.5{ }^{\circ} \mathrm{C}$ for $24 \mathrm{~h}$ in orbital shaker at $200 \mathrm{rpm}$ in the dark (Akhurst 1980). sterile glycerol was added to previously produced bacteria in YS medium at the range of $15 \%$ to storage of the bacteria, It was stocked at $-20{ }^{\circ} \mathrm{C}$ for using the next experiments.

\section{Egg isolation:}

Ten G. mellonella last instar larvae were inoculated with strains of $H$. bacteriophora as the range of 50 IJs each larva according to Susurluk et. al. $(2001,2003)$. Treated larvae were incubated at $25 \pm 1.5{ }^{\circ} \mathrm{C}$ for 3 days. Then, infected larvae were dissected and hermaphrodite individuals were collected. Approximately 150 or 200 individuals were enough for successful egg isolation. Fertilized hermaphrodite individuals were transferred into Ringer's solutions a glass tube containing pieces of razor blade.. To separate eggs from hermaphrodites, glass tube was treated with vortex for a minute. Then, suspension of egg-Ringer's was centrifuged for 2 minutes at $3000 \mathrm{rpm}$. The eggs were got a sediment deep of centrifuge tube. Then, supernatant was removed and filled up with fresh Ringer's solution and centrifuged. This treatment was repeated until supernatant was clear. After this process, supernatant was removed and the sterilization solution $(12 \% \mathrm{NaOCl}, 0.5 \mathrm{ml} ; 4 \mathrm{M} \mathrm{NaOH}, 1.5 \mathrm{ml}$; distilled water, $10 \mathrm{ml})$ was added on the eggs. Tubes containing eggs were shaken for 4 minutes and centrifuged at $2000 \mathrm{rpm}$ for 2 minutes. After centrifugation, the sterilization solutions were removed from the eggs and added YS medium. Centrifugation was repeated as described above. Eggs were transferred into the YS medium in the well plates after last centrifugation and then incubated $25 \pm 1.5^{\circ} \mathrm{C}$ for 2 days (Lunau et al., 1993). 


\section{Prepare of monoxenic nematode culture:}

The YS medium was inoculated with $P$. luminescens that previously isolated and then incubated in the orbital shaker at $200 \mathrm{rpm}$ and $25 \pm 1.5{ }^{\circ} \mathrm{C}$ in dark conditions for $24 \mathrm{~h}$. One or two drops were taken from grown bacteria in the YS and transferred to the WOUTS agar. The first stage juveniles, which had occurred hatching of eggs, were transferred to the WOUTS agar, being inoculated with the bacteria. Petri dishes were covered with parafilm and incubated at $25 \pm 1.5^{\circ} \mathrm{C}$ in the dark. The experiment was repeated five times for each strains of $H$. bacteriophora. The petri dishes were checked daily for observation of IJs growing (Lunau et al., 1993).

\section{Production of $\mathrm{H}$. bacteriophora strains on in vitro liquid culture:}

Symbiotic bacteria were prepared according to Akhurst (1980) for in vitro liquid culture production. A drop of bacteria from the YS medium was transferred to the BSA medium and this medium was incubated at $25 \pm 1.5^{\circ} \mathrm{C}$ in orbital shaker at $200 \mathrm{rpm}$ in the dark for $24 \mathrm{~h}$. This treatment was applied for each strain and the control. On the other hand, new generation IJs were climbed up the lid of petri dishes two week after the monoxenic nematode culture process. The IJs were placed into BSA, being inoculated with bacteria, and incubated at $25 \pm 1.5^{\circ} \mathrm{C}$ in orbital shaker at $200 \mathrm{rpm}$ in the dark, as well (Lunau et. al., 1993; Ehlers et. al., 1998; Ehlers, 2001). Fertile male and female individuals were appeared 10 days after incubation. New generation IJs were obtained approximately 3 weeks after inoculation.

\section{Hybridization of strains:}

At the start of this study, virulence of parent strains was determined. H.b. 6 (Antalya) strain with lowest virulence was used as standard negative control. Male and female individuals of H.b. 6 (Antalya) were crossbred with females or males of other strains on in vitro conditions.

Egg isolation, preparation of monoxenic nematode culture, production in BSA of H.b. 6, H.b. 17, H.b. 10, H.b. HIZ, H.b. HSU and H.b. 876 strains were carried out for hybridization as described above. $10^{\text {th }}$ day of EPN production in BSA liquid medium, fertile female and male individuals were arisen. As from $10^{\text {th }}$ day, BSA medium containing strains were opened and removed approximately $2 \mathrm{ml}$ and transferred into Petri dishes in the sterile conditions. This application was performed for each strain. All strains were examined under the inverted microscope individually. After microscopic examination, male or female individuals of H.b. 6 were selected and transferred the WOUTS agar, which had been inoculated with $P$. luminescens and incubated at $25 \pm 1.5{ }^{\circ} \mathrm{C}$ for 2 days. Female or males of any strain was transferred to same conditions with H.b. 6 for crossbreeding (Table 1). Petri dishes $(6 \mathrm{~cm}$ diameter) were covered with parafilm and incubated at $25 \pm 1.5{ }^{\circ} \mathrm{C}$ for 2 weeks. Petri dishes were controlled daily whether there was any mating between females and males.. Ten males and females, total twenty individuals were used for each strain in the experiment. Additionally, five unfertilized females were transferred to the WOUTS agar for each strain for the control. The treatment was repeated three times for all strains (Lunau et. al., 1993; Iraki et. al., 2000; Susurluk et. al., 2001; Ehlers et. al., 2001; Mukuka et. al., 2010 a,b,c,d).

Table1. Parent and Hybrid Strains

\begin{tabular}{|c|c|}
\hline Parent Strains & Hybrid Strains \\
\hline H.b. 6 (Antalya) \& X H.b. 876 (Çanakkale) ô & H.b. A \\
\hline H.b. 6 (Antalya) đ̊ X H.b. 876 (Çanakkale) $ᄋ$ & H.b. B \\
\hline H.b. 6 (Antalya) $q$ X H.b. 17 (Kırklareli) $\hat{\sigma}$ & H.b. C \\
\hline H.b. 6 (Antalya) $\widehat{o}$ X H.b. 17 (Kırklareli) 우 & H.b. D \\
\hline H.b. 6 (Antalya) $q$ X H.b. HIZ (İzmir) $\widehat{\jmath}$ & H.b. E \\
\hline H.b. 6 (Antalya) $\widehat{\partial}$ X H.b. HIZ (İzmir) $q$ & H.b. F \\
\hline H.b. 6 (Antalya) $q$ X H.b. HSU (Şanlıurfa) ${ }^{\lambda}$ & H.b. G \\
\hline H.b. 6 (Antalya) $\precsim$ X H.b. HSU (Şanlıurfa) $q$ & H.b. H \\
\hline H.b. 6 (Antalya) $q$ X H.b. 10 (Adana) $\hat{o}$ & H.b. K \\
\hline H.b. 6 (Antalya) $\partial$ X H.b. 10 (Adana) $q$ & H.b. L \\
\hline
\end{tabular}


The new generation IJs, which composed of hybridization, were climbed up the lid of petri dishes. They were harvested from Petri dishes and stored in the Ringer's solution at 4-8 ${ }^{\circ} \mathrm{C}$ (Kaya \& Stock, 1997).

\section{Virulence tests of hybrid strains}

Virulence of hybrid strains was determined with the same method as parent strains. The results were recorded as Lethal Dose $\left(L D_{50}, L D_{90}\right.$ and $\left.L D_{\text {mean }}\right)$ at the end of experiments.

\section{Statistical analysis}

Data belong to virulence value of parents and hybridized strains were analyzed by one-way ANOVA and followed by Least Significant Deviance (LSD) test for post-hoc comparisons using of JMP® 7.0. The minimum level of significance was taken as $P<0.05 . L_{50}$ and $L D_{90}$ values of parents and hybridized strains were calculated with probit analysis using program of BioStat $@ 2010$.

\section{Results}

\section{Virulence of parent strains}

H.b. 876 was the most effective strain against the last instars larvae of $G$. mellonella $\left(L_{50}=0.58\right.$, $\left.L D_{90}=21.43, L D_{\text {mean }}=11.01\right)$. The least effective strain was H.b. $6\left(L_{50}=5.20, L D_{90}=28.89, L D_{\text {mean }}=17.05\right)$, which was used as a standard for obtaining negative control. For this reason, H.b. 6 was crossbred with the other strains. The results are shown on Table 2 for other strains.

Table 2. $\mathrm{LD}_{50}, \mathrm{LD}_{90}$ and $\mathrm{LD}_{\text {mean }}$ values of parent strains on Galleria mellonella larvae

\begin{tabular}{lccc}
\hline Parent Strains & LD $_{50}$ & LD $_{90}$ & LD $_{\text {mean }}$ \\
\hline H.b. 6 (Antalya) & 5.20 & 28.89 & 17.05 \\
H.b. 876 (Çanakkale) & 0.58 & 21.43 & 11.01 \\
H.b. 17 (Kırklareli) & 4.98 & 27.56 & 16.27 \\
H.b. HIZ (İzmir) & 5.06 & 24.26 & 14.66 \\
H.b. HSU (Şanlıurfa) & 5.27 & 26.53 & 15.90 \\
H.b. 10 (Adana) & 5.42 & 26.56 & 15.99 \\
\hline
\end{tabular}

Virulence of strains was increased with increasing application dose. Parent strains caused mortality at the range of $13.33 \%$ and $60 \%$ against the larvae with dose of $5 \mathrm{IJs} / \mathrm{L}$ arva. At the dose of $75 \mathrm{IJs} /$ larva, all strains caused $100 \%$ mortality. All results are presented in Table 3.

Table 3. Percent mortalities that parent strains caused on Galleria mellonella larvae at different doses.

\begin{tabular}{|c|c|c|c|c|c|}
\hline \multirow[b]{2}{*}{ Strains } & \multicolumn{5}{|c|}{ Insect Mortality (\%) } \\
\hline & $\begin{array}{c}5 \mathrm{lJs} / \mathrm{Larva} \\
(\mathrm{F}=11.62 ; \mathrm{df}=5,12 ; \\
\mathrm{P}=0.0003)\end{array}$ & $\begin{array}{c}10 \mathrm{IJs} / \mathrm{Larva} \\
(\mathrm{F}=14.04 ; \mathrm{df}=5,12 \\
\mathrm{P}=0.0001)\end{array}$ & $\begin{array}{c}20 \mathrm{IJs} / \mathrm{Larva} \\
(\mathrm{F}=1.62 ; \mathrm{df}=5,12 \\
\mathrm{P}=0.2285)\end{array}$ & $\begin{array}{c}50 \mathrm{lJs} / \text { Larva } \\
(\mathrm{F}=3.39 ; \mathrm{df}=5,12 ; \\
\mathrm{P}=0.0386)\end{array}$ & $\begin{array}{c}75 \mathrm{lJs} / \text { Larva } \\
(\mathrm{F}=0 ; \mathrm{df}=5,12 ; \\
\mathrm{P}=1)\end{array}$ \\
\hline H.b. 6 & $43.33 \mathrm{bc}$ & $78.33 \mathrm{a}$ & $91.67 \mathrm{ab}$ & $91.67 \mathrm{ab}$ & $100.00 \mathrm{a}$ \\
\hline H.b. 876 & $60.00 \mathrm{a}$ & $83.33 \mathrm{a}$ & $100.00 \mathrm{a}$ & $100.00 \mathrm{a}$ & $100.00 \mathrm{a}$ \\
\hline H.b. 17 & $13.33 d$ & $30.00 \mathrm{c}$ & $88.33 a b$ & $100.00 \mathrm{a}$ & $100.00 \mathrm{a}$ \\
\hline H.b. HIZ & $50.00 a b$ & $85.00 \mathrm{a}$ & $83.33 b$ & $100.00 \mathrm{a}$ & $100.00 \mathrm{a}$ \\
\hline H.b. HSU & $40.00 \mathrm{bc}$ & $83.33 \mathrm{a}$ & $91.67 \mathrm{ab}$ & $91.67 a b$ & $100.00 \mathrm{a}$ \\
\hline H.b. 10 & $31.67 \mathrm{c}$ & $50.00 \mathrm{~b}$ & $88.33 a b$ & $88.33 \mathrm{~b}$ & $100.00 \mathrm{a}$ \\
\hline
\end{tabular}

\section{Virulence of hybrid strains}

The most and the least effective hybrid strains were H.b. A $\left(L D_{50}=0.0096, L D_{90}=20.6637\right)$ and H.b. $B\left(L D_{50}=11.2499, L D_{90}=39.0115\right.$. The $L D_{50}$ values of the all hybrid strains were found below 1 except H.b. $B$ and H.b. L, those of which were detected between ca. 20 and 41. Results are summarized in Table 4. 
Table 4. $L D_{50}, L D_{90}$ and $L D_{\text {mean }}$ values of hybrid strains

\begin{tabular}{|c|c|c|c|}
\hline Hybrid Strains & $\mathrm{LD}_{50}$ & $\mathrm{LD}_{90}$ & $\mathrm{LD}_{\text {mean }}$ \\
\hline H.b. A (H.b. $6 q \times$ H.b. 876 ) & 0.00960 & 20.6637 & 10.33665 \\
\hline H.b. B (H.b. 6 ○े $\times$ H.b. 876 o) & 10.2499 & 37.0115 & 24.13070 \\
\hline 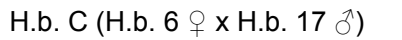 & 0.54550 & 26.1796 & 13.36255 \\
\hline H.b. D (H.b. $6 \curvearrowright$ x H.b. 17 ) & 0.47680 & 33.4722 & 16.97450 \\
\hline H.b. E (H.b. 6 \& $\times$ H.b. HIZ $\left.{ }^{\lambda}\right)$ & 0.07880 & 20.7189 & 10.39885 \\
\hline H.b. F (H.b. $6 \curvearrowright$ x H.b. HIZ +$)$ & 0.23870 & 21.9252 & 11.08195 \\
\hline 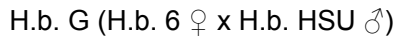 & 0.15470 & 29.0246 & 14.58965 \\
\hline H.b. H (H.b. 6 × x H.b. HSU $q)$ & 0.40400 & 29.3109 & 14.85745 \\
\hline H.b. K (H.b. 6 \& $\times$ H.b. 10 ふ) & 0.38020 & 24.9347 & 12.65745 \\
\hline H.b. L (H.b. $6 \bigcirc$ x H.b. 10 क) & 7.32090 & 41.6751 & 24.49800 \\
\hline
\end{tabular}

Virulence of hybrid strains varied from $26.67 \%$ to $83.3 \%$ at the application dose of $5 \mathrm{IJs} / \mathrm{Larva}$. The most effective strain was H.b. E. Besides that, strains of H.b. H and H.b. K and H.b. A were not significantly different from H.b. E at the dose of $5 \mathrm{IJs} / \mathrm{L}$ arva. The least effective strain was H.b. B, and followed by H.b. $L$ and H.b. G which were statistically at the same group as H.b B., at the same application dose. The most virulent dose was $75 \mathrm{IJs} / \mathrm{larva}$ and all insect larvae were killed by all strains (Table 5).

Table 5. Virulence values of hybrid strains at all applied doses

\begin{tabular}{|c|c|c|c|c|c|}
\hline \multirow[b]{2}{*}{ Strains } & \multicolumn{5}{|c|}{ Insect Mortality (\%) } \\
\hline & $\begin{array}{c}5 \mathrm{IJ} / \text { Larva } \\
(\mathrm{F}=9.6129 ; \mathrm{df}=9 \\
20 ; \mathrm{P}=0.0001)\end{array}$ & $\begin{array}{c}10 \mathrm{IJ} / \text { Larva } \\
(\mathrm{F}=11.9352 ; \mathrm{df}=9 \\
20 ; \mathrm{P}=0.0001)\end{array}$ & $\begin{array}{c}20 \mathrm{IJ} / \text { Larva } \\
(\mathrm{F}=11.2540 ; \mathrm{df}=9 \\
20 ; \mathrm{P}=0.0001)\end{array}$ & $\begin{array}{c}50 \mathrm{IJ} / \text { Larva } \\
(\mathrm{F}=3.3472 ; \mathrm{df}=9 \\
20 ; \mathrm{P}=0.0117)\end{array}$ & $\begin{array}{c}75 \mathrm{lJ} / \text { Larva } \\
(\mathrm{F}=0 ; \mathrm{df}=9,20 ; \\
P=1)\end{array}$ \\
\hline H.b. A & $70.00 \mathrm{abc}$ & $98.33 \quad a$ & $98.33 \quad \mathrm{a}$ & $100.00 \mathrm{a}$ & $100.00 \mathrm{a}$ \\
\hline H.b. B & 26.67 e & 60.00 & $65.00 \quad \mathrm{~d}$ & $98.33 a b$ & $100.00 \mathrm{a}$ \\
\hline H.b. C & $56.67 \mathrm{bcd}$ & $73.33 \mathrm{~cd}$ & $90.00 \mathrm{abc}$ & $98.33 \mathrm{ab}$ & $100.00 \mathrm{a}$ \\
\hline H.b. D & $55.00 \mathrm{~cd}$ & $68.33 \mathrm{de}$ & $88.33 \mathrm{bc}$ & $95.00 \mathrm{bc}$ & $100.00 \mathrm{a}$ \\
\hline H.b. E & $83.33 \mathrm{a}$ & $90.00 \mathrm{ab}$ & $96.67 \mathrm{ab}$ & $100.00 a$ & $100.00 \mathrm{a}$ \\
\hline H.b. F & $65.00 \mathrm{bc}$ & 81.67 bc & $91.67 \mathrm{abc}$ & $100.00 \mathrm{a}$ & $100.00 \mathrm{a}$ \\
\hline H.b. G & $40.00 \mathrm{de}$ & $88.33 \mathrm{ab}$ & $91.67 \mathrm{abc}$ & $100.00 a$ & $100.00 \mathrm{a}$ \\
\hline H.b. H & $73.33 \mathrm{ab}$ & $85.00 \quad b$ & $86.67 \quad c$ & $96.67 \mathrm{ab}$ & $100.00 \mathrm{a}$ \\
\hline H.b. K & $71.67 \mathrm{abc}$ & $80.00 \mathrm{bc}$ & $93.33 \mathrm{abc}$ & $98.33 \mathrm{ab}$ & $100.00 \mathrm{a}$ \\
\hline
\end{tabular}

\section{Comparison of virulence values of parent and hybrid strains}

The mean mortality of $G$. mellonella was between 13.33 and $83.33 \%$ at the dose of 5 IJs/Larva. The results showed that the most effective hybrid strain was H.b. E (83.33\%) followed by H.b. $H$ (73.33\%). All hybrid strains were more effective than their parents were except H.b. B $\left(L D_{50}=11.2499\right.$, $\left.\mathrm{LD}_{90}=37.0115\right)$ and H.b. $\mathrm{L}\left(\mathrm{LD}_{50}=7.3209, \mathrm{LD}_{90}=41.6751\right)(\mathrm{F}=14.3843 ; \mathrm{df}=15,32 ; \mathrm{P}=0.0001)$ (Figure 1).

The results indicated that seven of hybridized strains of $H$. bacteriophora were more effective than their parents (Figure 1). Female and male individuals of parents had different effects on virulence of hybrid strains. Male parents were more effective than females; $57.1 \%$ of more effective hybrid strains and $42.9 \%$ of those were originated from males and females, respectively (Table 3 and 4 ). 


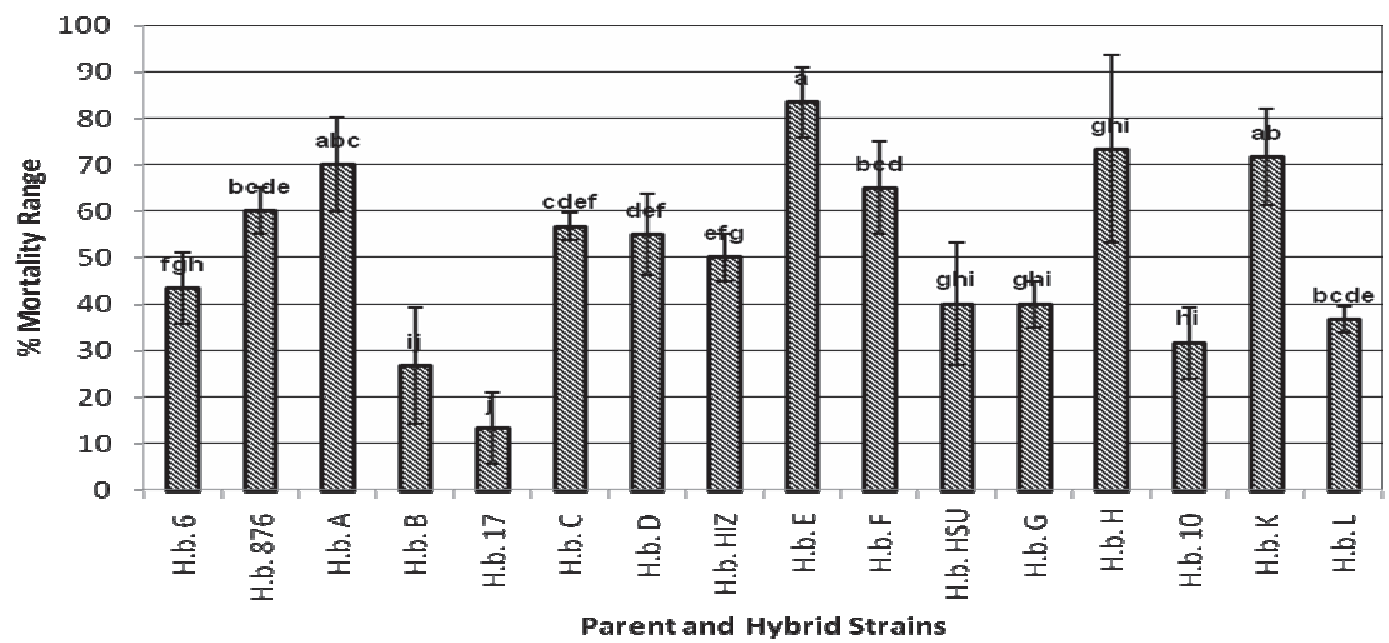

Figure 1. Virulence of parents and hybrids of $H$. bacteriophora at the applied dose of $5 \mathrm{IJ} / \mathrm{Larva}$.

\section{Discussion}

Hybridization has been used for improvement of target organisms to get better individuals of the organism. By this means, more productive products or more capable living material can be obtained to serve several areas. Biological control agents are successfully used in some agricultural areas. However, they need to be improved for being more effective. One of the most effective tools is hybridization of them. Entomopathogenic nematodes (EPNs), which are used against various insect pests, are recently hybridized to get more tolerant strains to some environmental conditions that can have major effects on establishment and persistence of EPNs (Susurluk \& Ehlers, 2008). Generally, heat and desiccation tolerant strains of EPNs were improved by hybridization (Strauch et. al., 2004; Mukuka et. al., $2010 \mathrm{c}$, d; Susurluk et. al., 2013 a, b; Ulu \& Susurluk, 2014). Very limited fitness/hybrid vigor studies were carried out (Mukuka et. al., 2010 b). In the present study, six strains of $H$. bacteriophora, which were isolated from different regions of Turkey, were hybridized with each other and their virulence were compared with their parents. The aim of the study was to obtain more effective hybrid strains of $H$. bacteriophora, which are used several countries against several insects. This study is also important for detecting if effective features of the species can be transferred by heritability or not. Turkish strains were firstly hybridized to obtain more effective strains. Hybridization of EPNs was firstly advised by Gaugler (1986), he indicated that the stress factors on $\mathrm{H}$. bacteriophora, such as heat and desiccation, were reduced via hybridization of strains, which adapted different climatic zone. He showed that producing of tolerant strains against desiccation and heat were possible via crossbreeding. . Crossbreeding method was used for hybridization; moreover this method is generally used for identification of unknown species (Susurluk et al., 2001; Strauch et. al., 2004; Mukuka et. al., 2010 c, d; Susurluk et. al., 2013 a, b).

In the present study, this method was successfully applied in in vitro conditions. Mukuka et al. (2010 b) stated that some heat and desiccation tolerant hybrid strains had more virulence than hybrid commercial strain EN01 of $\mathrm{H}$. bacteriophora, but some of them had lower effect. However, they were not compared the hybrid starins with their parents for the virulence. They expressed that the virulence depends on the symbiotic bacterium (Han and Ehlers, 2000), so that the bacterium that originated from different females can change virulence capabilities. In the present study, the same bacterium was used in all cross breeding experiment. Therefore, the differences of virulence were not related with the symbiotic bacterium. 
As an important finding of the study, female and males of parents play different roles on heritability to virulence of hybrid strains. Males are more effective than females and this is the first report. However, it is now unknown the reason of the difference that depends on the sexuality of parent. After this result, it is needed to detect whether there is also different virulence between female and male IJs or not.

Increasing of doses triggers positively efficacy of EPNs, the present results confirmed this judgment. There was a correlation between increasing of doses and mortality. Several studies were accordance with the present conclusion (Susurluk et al., 2001; Kepenekçi, 2004).

Some studies on hybrid vigor of some animal and plants indicated that if hybrid vigor results in higher densities, larger body sizes, or more rapid growth of organisms in hybrid populations, the impacts of hybridization will almost certainly extend to other members of the ecological community (Benjamin et al. 2007). Similarly, the whole study indicated that hybrid $H$. bacteriophora with high effective capacity can be obtained by the using hybridization. By this means, success and sustainability of EPNs in biological control can be increased. This study is a milestone in contributing to the improvement of more effective $H$. bacteriophora. Thus, new hybrid Turkish strains of $H$. bacteriophora might be successfully used against especially soil dwelling insect pests in Turkey.

\section{Acknowledgement}

This study was financially supported by the TUBITAK (The Scientific and Technological Research Council of Turkey), Project number: TOVAG 1100161.

\section{References}

Akhurst, R.J., 1980. Morphological and functional dimorphism in Xenorhabdus spp., bacteria symbiotically associated with insect pathogenic nematodes Neoaplectana and Heterorhabditis. Journal of General Microbiology, 121: 303-309.

Akhurst, R.J., 1983. Neoaplectana species: Specificity of association with bacteria of the genus Xenorhabdus. Experimental Parasitology, 55: 258-263.

Bedding, R.A. \& A.S., Molyneux, 1982. Penetration of insect cuticle by infective juveniles of Heterorhabditis spp. (Heterorhabditidae, Nematoda). Nematologica, 28 (3): 354-359.

Benjamin M. Fitzpatrick \& H., Bradley Shaffer, 2007. Introduction history and habitat variation explain the landscape genetics of hybrid tiger slamanders. Ecological Applications, 17: 598-608.

Bird, A.F. \& R.J., Akhurst, 1983. The nature of the intestinal vesicle in nematodes of the family Steinernematidae. International Journal of Parasitology, 13: 599-606.

Edmands, S. 1999. Heterosis and outbreeding depression in interpopulation crosses spanning a wide range of divergence. Evolution, 53:1757-1768.

Ehlers, R.-U., 1996. Current and future use of nematodes in biocontrol: Practise and commercial aspects in regard to regulatory policies. Biocontrol Science and Technology, 6 (3): 303-316.

Ehlers, R.-U., S., Lunau, K., Krasomil-Osterfeld \& K.H., Osterfeld, 1998. Liquid culture of the entomopathogenic nematode-bacterium complex Heterorhabditis megidis/Photorhabdus luminescens. BioControl, 43(1): 77-86.

Ehlers, R.-U., 2001. Mass production of entomopathogenic nematodes for plant protection. Applied Microbiology and Biotechnology, 56: 623-633.

Ehlers, R.-U., J., Oestergaard, S., Hollmer, M., Wingen \& O., Strauch, 2005. Genetic selection for low tolerance and low temperature activity of the entomopathogenic nematode-bacterium complex Heterorhabditis bacteriophora-Photorhabdus luminescens. BioControl, 50: 699-716.

Flanders, K.L., J.M., Miller \& E.J., Shields, 1996. In vivo production of Heterorhabditis bacteriophora 'Oswego' (Rhabditida: Heterorhabditidaw), a potential biological control agent for soil-inhabiting insects in temperature regions. Journal of Economic Entomology, 89: 373-380. 
Forst, S. \& K., Nealson, 1996. Molecular biology of the symbiotic pathogenic bacteria Xenorhabdus spp. and Photorhabdus spp. Microbial Reviews, 60 (1): 21-43.

Friedman, M.J., 1990. Commercial production and development, pp: 153-172. In: Entomopathogenic Nematodes in Biological Control, Ed.: Gaugler, K., Kaya, H.K., CRC, Boca Raton, Florida.

Gaugler, R. 1986. Entomogenous nematodes and their prospects for genetic improvement: Biotechnology in Invertebrate Pathology and Cell Culture, Ed.: Maramorosch, K., Academic Press, San Diego, pp: 457-484.

Gaugler, R., J.F., Campbell \& T.R., McGuire, 1989. Selection for host-finding in Steinernema feltiae. Journal of Invertebrate Pathology, 54: 363-372.

Gaugler, R. \& R., Han, 2002. Preface, pp: 9-10. In: Entomopathogenic Nematology, Ed: Gaugler, R., CABI, UK.

Grewal, P.S., S., Selvan \& R., Gaugler, 1994. Thermal adaption of entomopathogenic nematodes: Niche breadth for infection, establishment, and reproduction. Journal of Thermal Biology, 19: 245-253.

Glazer, I., R., Gaugler \& D., Segal, 1991. Genetics of the entomopathogenic nematode Heterorhabditis bacteriophora (strain HP88): the diversity of beneficial traits. Journal of Nematology, 23: 324-333.

Han, R. \& R.U. Ehlers, 2000. Pathogenicity, development and reproduction of Heterorhabditis bacteriophora and Steinernema carpocapsae under axenic in vivo conditions. Journal of Invertebrate Pathology, 75: 55-58.

Hazır, S., N. Keskin, S.P., Stock, H.K. Kaya \& S. Özcan, 2003. Diversity and distribution of entomopathogenic nematodes (Rhabditida: Steinernematidae and Heterorhabditidae) in Turkey. Biodiversity and Conservation, 12: $375-386$.

Iraki, N., N., Salah, N., Sansour, D., Segal, I., Glazer, S.A., Johnigk, M., Hussein \& R.-U., Ehlers, 2000. Isolation and characterization of two entomopathogenic nematode strains, Heterorhabditis indica (Nematoda, Rhabditia), from the West Bank, Palestinian Territories. The Journal of Applied Entomology, 124: 375-380.

Johnigk, S.-A. \& R.-U., Ehlers, 1999a. Juvenile development and life cycle of Heterorhabditis bacteriophora and $H$. indica (Nematoda: Heterorhabditidae). Nematology, 1: 251-260.

Johnigk, S.-A. \& R.-U., Ehlers, 1999b. Endotokia matricida in hermaphrodites of Heterorhabditis spp. and the effect of the food supply. Nematology, 1: 717-726.

Kaya, H.K. \& R., Gaugler, 1993. Entomopathogenic Nematodes. Annual Review of Entomology, 38: $181-206$.

Kaya, H.K. \& S.P., Stock, 1997. Techniques in insect nematology, pp: 281-324. In: Manual of techniques in insect pathology, Ed: Lacey, L.A., CA: Academic Press, San Diego.

Kepenekçi, I. 2002. Entomopathogenic nematodes (Rhabditida) in the Mediterranean Region of Turkey. Nematologia Mediterranea, 21: 13-16.

Kepenekçi, I. \& I.A., Susurluk, 2003. Three entomopathogenic nematodes (Rhabditida) from Turkey. Pakistan Journal of Nematology, 21: 19-23.

Kepenekçi, İ., A., Gökçe \& R., Gaugler, 2004. Virulence of three species of entomopathogenic nematodes to the chestnut weevil, Curculio elephas (Coleoptera: Curculionidae). Nematropica,34 (2): 199-204.

Lunau, S., S., Stoessel, A.J., Schmidt-Peisker \& R.-U., Ehlers, 1993. Establishment of monoxenic inocula for scalling up in vitro cultures of the entomopathogenic nematodes Steinernema spp. and Heterorhabditis spp. Nematologica, 39: 385-399.

Mukuka, J., O., Strauch, L., Waeyenberge, N., Viaene, M., Moens \& R.-U. Ehlers, 2010a. Heat tolerance among different strains of the entomopathogenic nematode Heterorhabditis bacteriophora. BioControl, 55:423-434.

Mukuka, J., O., Strauch, C., Hoppe \& R.-U., Ehlers, 2010b. Fitness of heat and desiccation tolerant hybrid strains of Heterorhabditis bacteriophora (Rhabditidomorpha: Heterorhabditidae). Journal of Pest Science, 83:281-287.

Mukuka, J., O., Strauch, C., Hoppe \& R.-U., Ehlers, 2010c. Improvement of heat and desiccation tolerance in Heterorhabditis bacteriophora through cross-breeding of tolerant strains and successive genetic selection. BioControl, 55:511-521.

Mukuka, J., O., Strauch \& R.-U., Ehlers, 2010d. Variability in desiccation tolerance among different strains of the entomopathogenic nematode Heterorhabditis bacteriophora. Nematology, 12(5):711-720.

Poinar, G.O. JR., 1975. Description and biology of a new parasitic rhabditoid Heterorhabditis bacteriophora new gen, new species. Nematologica, 21: 463-470. 
Comparison of virulence of hybridized entomopathogenic nematode Heterorhabditis bacteriophora (Rhabditida: Heterorhabditidae) strains and their parents

Poinar, G.O. JR., G.M., Thomas \& R., Hess, 1977. Characteristics of the specific bacterium associated with Heterorhabditis bacteriophora (Heterorhabditidae: Rhabditida). Nematologica, 23: 97-102.

Poinar, G.O. JR., 1990. Biology and Taxonomy of Steinernematidae and Heterorhanditidae, pp: 23-62. In: Entomopathogenic Nematodes in Biological Control, Ed: Gaugler, R., Kaya, H.K., CRC Press, Boca Raton, Florida.

Özer, N., N., Keskin \& Z. Kırbaş, 1995. Occurrence of entomopathogenic nematodes (Steinernematidae: Heterorhabditidae) in Turkey. Nematologica, 41: 639-640.

Shapiro-Ilan, D.I. \& R., Gaugler, 2002. Production technology for entomopathogenic nematodes and their bacterial symbionts. Journal of Industrial Microbiology and Biotechnology, 28: 137-146.

Strauch, O., S., Stoessel \& R.-U., Ehlers, 1994. Culture conditions define automictic or amphimictic reproduction in entomopathogenic rhabditid nematodes of the genus Heterorhabditis. Fundamental and Applied Nematology, 17: $575-582$.

Strauch, O., J., Oestergaard, S., Hollmer \& R.-U., Ehlers, 2004. Genetic improvement of the desiccation tolerance of the entomopathogenic nematode Heterorhabditis bacteriophora through selective breeding. Biological Control, 31: $218-226$.

Susurluk, A., I., Dix, E., Stackebrandt, O., Strauch, U., Wyss \& R.-U. Ehlers, 2001. Identification and ecological characterisation of three entomopathogenic nematode-bacterium complex from Turkey. Nematology, 3 (8): 833-841.

Susurluk, A. \& R.-U., Ehlers, 2008. Field persistence of the entomopathogenic nematode Heterorhabditis bacteriophora in different crops. BioControl, 53: 627-641.

Susurluk, I.A., I., Ünlü \& I.,Kepenekçi, 2003. Host finding behaviour of two different Turkish isolates of entomopathogenic nematode species, Heterorhabditis bacteriophora Poinar 1976 (Rhabditida: Heterorhabditidae). Turkish Journal of Biology, 27 (4): 203-207.

Susurluk, I.A., 2006. Comparison of some biological characterizations of the entomopathogenic nematodes, Steinernema weiseri and S. feltiae (Rhabditida: Steinernematidae), isolated in Turkey. Turkish Journal of Agricultural Science, 12 (4): 340-344.

Susurluk, I.A., N.A., Kumral, A., Peters, U., Bilgili \& E., Açıkgöz, 2009. Pathogenicity, reproduction and foraging behaviours of some entomopathogenic nematodes on a new turf pest, Dorcadion pseudopreissi (Coleoptera: Cerambycidae). Biocontrol Science and Technology, 19 (6): 585-594.

Susurluk, I.A., N. A., Kumral, U., Bilgili \& E., Açıkgöz, 2011. Control of a new turf pest, Dorcadion pseudopreissi (Coleoptera: Cerambycidae), by the entomopathogenic nematode Heterorhabditis bacteriophora. Journal of Pest Science, 84: 321-326.

Susurluk, I.A., T.C., Ulu \& Y., Kongu, 2013 a. Tolerances of hybridized entomopathogenic nematode Heterorhabditis bacteriophora (Rhabditida: Heterorhabditidae) strains to heat and dessication. Türkiye Entomoloji Dergisi, 37 (2): 221-228.

Susurluk, I.A., Y. Kongu \& T.C., Ulu, 2013 b. Quality control of in vitro produced Heterorhabditis bacteriophora (Rhabditida: Heterorhabditidae) strains isolated from Turkey. Türkiye Entomoloji Dergisi, 37 (3): $283-291$.

Ulu, T.C. \& I.A., Susurluk 2014. Heat and desiccation tolerances of Heterorhabditis bacteriophora strains and relationships between their tolerances and some bioecological characteristics. ISJ-Invertebrate Survival Journal, 11: 4-10.

Wang, Y. \& R., Gaugler, 1998. Host and penetration site location by entomopathogenic nematodes against Japanese beetle larvae. Journal of Invertebrate Pathology, 72 (3): 313-318.

White, G.F., 1927. A Method for Obtaining Infective Nematode Larvae from Culture. Science, 66: 302-303.

Wiesner, A., 1993. Die Induktion der Immunabwehr eines Insekts (Galleria mellonella, Lepidoptera) durch synthetische Materialien und arteigene Haemolymphfaktoren. PhD Thesis in Berlin, 107 pp.

Zioni, S., I., Glazer \& D., Segal, 1992. Phenotypic and genetic analysis of a mutant of Heterorhabditis bacteriophora strain HP88. Journal of Nematology, 24: 359-364. 